\title{
Micropropagation of Salvia guaranitica Benth. through Axillary Shoot Proliferation
}

\author{
Sergio Echeverrigaray ${ }^{*}$, Rosane Postingher Carrer and Luciana Bavaresco Andrade \\ Instituto de Biotecnologia; Universidade de Caxias do Sul; Rua Francisco G. Vargas, 1130; 95070-560; Caxias do \\ Sul - RS - Brasil
}

\begin{abstract}
Nodal segments from greenhouse grown adult plants of Salvia guaranitica were used to evaluate the effect of culture media and growth regulators on the micropropagation and growth. The highest multiplication rate was obtained on Murashige and Skoog (MS) medium supplemented with $2.22 \mu M$ of 6-benzylaminopurine (BAP). The best condition for rooting was MS medium with $2.85 \mu M$ indole-3-acetic acid (IAA). Rooted plants were successfully acclimatized and exhibited a normal development until maturity. Using the described protocol, approximately 35 plants per explant were obtained after three months.
\end{abstract}

Key words: growth regulators, shoot culture, axillary buds

\section{INTRODUCTION}

Salvia guaranitica Benth. belongs to the subgenus Calosphace, characteristic of South and Central America (Harley and Heywood, 1992). It is an ornamental and medicinal plant originally from South Brazil, Paraguay, Uruguay and Argentina, and actually cultivated in North America and Europe. The popular names attributed to this species are: blue anise sage, Brazilian sage, anise sage, among others. It is a semi-woody perennial subshrub that exhibits a bushy, somewhat open habit with upright, branching, square, dark green stems typically growing $90-150 \mathrm{~cm}$ tall. Their leaves (5 to $13 \mathrm{~cm}$ long) are dark green, ovate, wrinkled, pointed and lightly-toothed. This species flower from mid-summer into fall and is characterized by terminal spikes (20 to $40 \mathrm{~cm}$ long) with 3 to 12 bilabiate, tubular, deep blue flowers ( 3 to $5 \mathrm{~cm}$ long) with purple-blue calyxes
(Pereira, 1971). This giant sage species has been characterized as octaploid with $2 \mathrm{n}=84$ to 88 , the largest chromosome number within the genus Salvia (Harley and Heywood, 1992; Alberto et al., 2003).

Different from other species of the genus Salvia, the major components of the essential oil of $S$. guaranitica are sesquiterpene hydrocarbons (germacrene $\mathrm{D}, \beta$-elemene, $\beta$-caryophyllene and $\beta$ bourbonene), whith about $4 \%$ monoterpenes (Vallverdu et al., 2005; Carrer et al., 2007). Sedative and hypnotic properties of the ethanolic extracts of S. guaranitica (Medina et al., 1989) have been associated with the presence of high concentrations of the flavonoid cirsiliol and caffeic acid ethyl ester (Mader et al., 1996).

The propagation of $S$. guaranitica is made by the seeds or stem cutting. However, to our knowledge, there is no documented literature concerning the micropropagation of this species. Some other

*Author for correspondence: selaguna@ucs.br 
species of the genus Salvia have previously been propagated (Frett, 1986, Hosoki and Tahara, 1993, Cuenca and Amo-Marco, 2000; Avato et al., 2005).

In this context, the objective of the present work was to develop an in vitro propagation protocol for $S$. guaranitica, contributing to the conservation and commercial propagation of this species.

\section{MATERIAL AND METHODS}

Nodal segments measuring 2 to $3 \mathrm{~cm}$ in length were excised from two year-old plants of a commercial population of $S$. guaranitica Benth. (Floricultura Úrsula, Nova Petrópolis, RS, Brazil) between September and Dezember 2003, disinfected first in $70 \%$ ethanol for $30 \mathrm{~s}$ and then in a $1 \mathrm{~g} \mathrm{dm}^{-3}$ sodium hypochlorite solution containing $0.01 \%$ (v/v) Tween-20 for $20 \mathrm{~min}$. After rinsing with sterile distilled water, the nodal segments with two dormant axillary buds were implanted vertically onto the culture media. Cultures were maintained at $25 \pm 2{ }^{\circ} \mathrm{C}$ with 16 -h photoperiod and irradiance of $10-20 \mu \mathrm{mol} \mathrm{m} \mathrm{m}^{-2}$, and evaluated after a period of 30 days. The culture media used in this work consisted of the salt and vitamin solutions of Murashige and Skoog (1962; MS), Linsmaier and Skoog (1965; LS), Gamborg et al. (1968; B5), Chu et al. (1975; N6), and Quoirin and Lepoivre (1977; QL), with $0.4 \mathrm{mg}$ $\mathrm{dm}^{-3}$ thiamine, $100 \mathrm{mg} \mathrm{dm}^{-3}$ inositol, $3 \%$ sucrose, and $0.7 \%$ agar (Merck, Darmstadt, Germany).

The effect of growth regulators on micropropagation was evaluated on MS basal medium supplemented with 2.22 and $4.44 \mu \mathrm{M}$ 6benzylaminopurine (BAP), kinetin (KIN), 2isopentenyladenine (2iP), and thidiazuron (TDZ). The effect of BAP concentrations ( 0 to $8.88 \mu \mathrm{M})$, as well as the combination of BAP (2.22 and 4.44 $\mu \mathrm{M})$ with the auxins indole-3-acetic acid (IAA) and indole-3-butyric acid (IBA) was also tested. The effect of IAA, IBA and NAA $(\alpha-$ naphthaleneacetic acid) concentration on rooting was evaluated. The experimental designs were fully randomized with three replicates of 30 explants per treatment. Data were analyzed statistically by the analysis of variance (ANOVA), followed by the Tukey test, at a level of significance set of $5 \%$.

Rooted plantlets were acclimatized for 20 days in plastic chambers containing a sterilized mixture of sand and soil (1:1). Acclimatized plants were transferred to the greenhouse and evaluated periodically for morphologic traits.

\section{RESULTS AND DISCUSSION}

Initially the effect of five culture media supplemented with $2.22 \mu \mathrm{M}$ BAP was evaluated on the multiplication and growth of $S$. guaranitica. The results (Fig. 1) showed that MS and LS media supported the same multiplication rate (4.30 to 4.25 shoots/explant), whereas the number of shoots per explant on N6, B5 and QL were significantly lower $(<1.5$ shoots/explant $)$. Moreover, shoot length was significantly higher on MS and LS media (data not shown).

These results could be attributed to the $\mathrm{NO}_{3}{ }^{-} / \mathrm{NH}_{4}{ }^{+}$ ratio on MS and LS media, both with 66:34, compared with the others (92.44:7.56 for B5, 80:20 for N6, and 83:17 for QL), or to the difference in total nitrogen content, $60.01 \mathrm{mM}$ on MS and LS media, and less than $35 \mathrm{mM}$ on the other media. The nitrogen $\mathrm{NO}_{3}{ }^{-} / \mathrm{NH}_{4}{ }^{+}$ratio is considered an important factor for nitrogen uptake and $\mathrm{pH}$ regulation during plant tissue culture, and high total nitrogen concentration can modify plant response to growth regulators enhancing the morphogenesis and plant growth (George, 1993). MS medium has been used with success in the micropropagation of other species of Salvia, such as S. leucantha (Hosoki and Tahara, 1993), S. valentina and S. blancoana (Cuenca and AmoMarco, 2000), S. officinalis (Avato et al., 2005), and S. brachyodon (Misic et al., 2006). Independent of the culture media, the multiplication was obtained by the development of axillary buds. Basal callus and adventitious buds were not observed. 


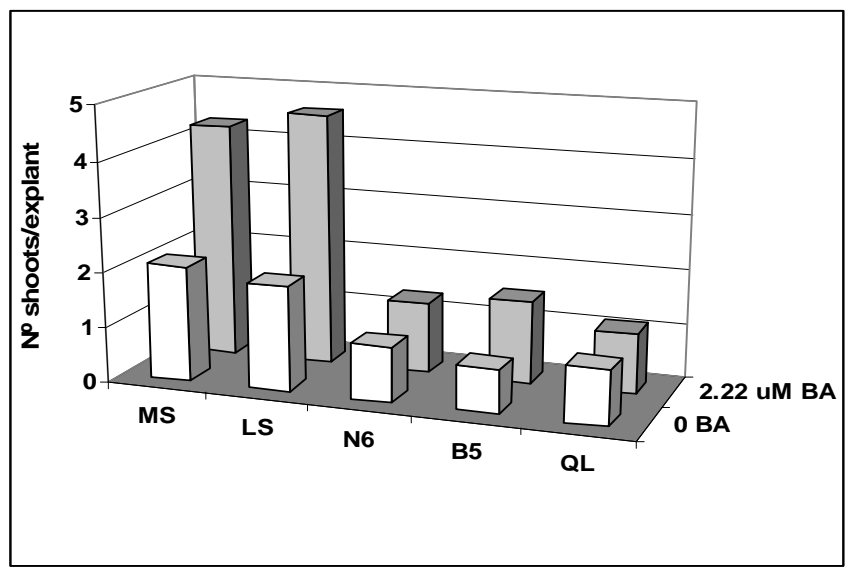

Figure 1 - The effect of culture medium on the micropropagation of $S$. guaranitica. Mean and SE. $(\mathrm{n}=30)$. MS- Murashige and Skoog, LS- Linsmaier and Skoog, N6- Chu et al., B5Gamborg et al., QL- Quoirin and Lepoivre.

To test whether different cytokinins influenced the multiplication of $S$. guaranitica, axillary buds were inoculated on MS medium, supplemented with BAP, KIN, 2-iP, and TDZ in two concentrations (Table 1). The media supplemented with BAP (2.22 and $4.44 \mu \mathrm{M})$ were the most effective in promoting the shoot development, but reduced shoot length. Further tests showed that shoot multiplication was dependent on BAP concentration (Fig. 2). The highest multiplication rates were achieved on MS media supplemented with $2.22 \mu \mathrm{M}$. Under high concentrations of BAP
(4.44 and $8.88 \mu \mathrm{M}$ ), shoots were stunted due to hyperhydricity.

Hyperhydricity was also a limiting factor in the propagation of other Lamiaceae species, such as Lavandula dentata (Echeverrigaray et al., 2005) and Salvia miltiorrhiza (Chen et al., 2005). As observed in other Salvia species (Cuenca and Amo-Marco, 2000, Misic et al., 2006), S. guaranitica exhibited a strong apical dominance that resulted in slow growth of axillary buds and no production of adventitious buds, consequently, a low multiplication rate.

Table 1 - The effect of different cytokinins on the propagation and growth of $S$. guaranitica. Means \pm SE $(n=60)$. Within each column, values followed by the same letter are not significantly different (5\% level- Tukey's test)

\begin{tabular}{cccc}
\hline & {$[\boldsymbol{\mu M}]$} & Shoot length $[\mathbf{c m}]$ & Number of shoots per explant \\
\hline Control & 0 & $5.59 \pm 0.57^{\mathrm{ab}}$ & $1.95 \pm 0.23^{\mathrm{cd}}$ \\
BAP & 2.22 & $3.35 \pm 0.22^{\mathrm{cd}}$ & $4.40 \pm 0.33^{\mathrm{a}}$ \\
& 4.44 & $2.42 \pm 0.21^{\mathrm{d}}$ & $3.32 \pm 0.43^{\mathrm{b}}$ \\
$2-\mathrm{iP}$ & 2.22 & $3.54 \pm 0.32^{\mathrm{cd}}$ & $1.75 \pm 0.12^{\mathrm{d}}$ \\
& 4.44 & $4.36 \pm 0.47^{\mathrm{bc}}$ & $2.67 \pm 0.34^{\mathrm{bc}}$ \\
$\mathrm{TDZ}$ & 2.22 & $4.77 \pm 0.46^{\mathrm{bc}}$ & $1.76 \pm 0.17^{\mathrm{d}}$ \\
& 4.44 & $3.84 \pm 0.39^{\mathrm{cd}}$ & $1.96 \pm 0.26^{\mathrm{cd}}$ \\
KIN & 2.22 & $6.62 \pm 0.64^{\mathrm{a}}$ & $1.55 \pm 0.16^{\mathrm{d}}$ \\
& 4.44 & $6.71 \pm 0.45^{\mathrm{a}}$ & $1.56 \pm 0.18^{\mathrm{d}}$
\end{tabular}




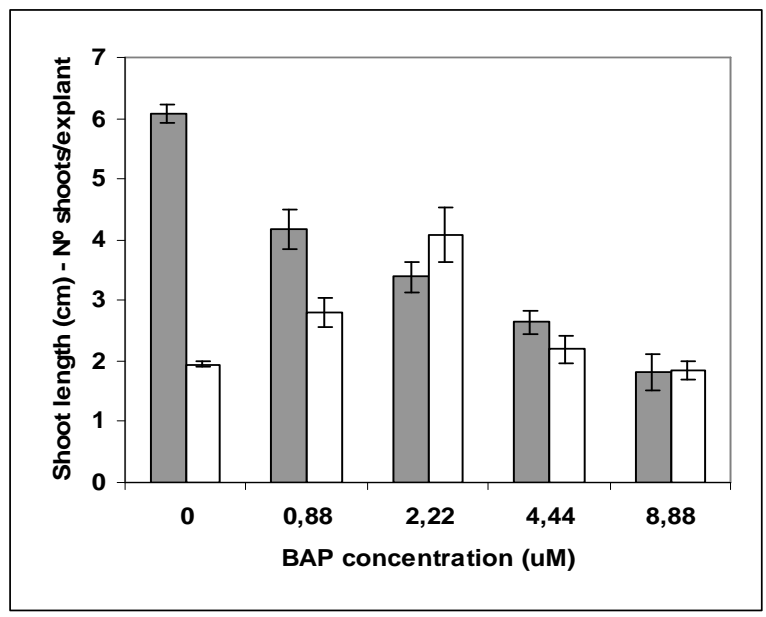

Figure 2 - The effect of BAP concentration on the micropropagation of $S$. guaranitica. Shoot length (dark bars) and number of shoots/explant (white bars). Mean and SE, $n=60$.

In order to increase the multiplication rate, combinations of 6-benzylaminopurine (2.22 and $4.44 \mu \mathrm{M})$ with IAA $(1.14,2.85$ and $5.71 \mu \mathrm{M})$ or IBA $(0.98,2.46$, and $4.92 \mu \mathrm{M})$ were evaluated. Explants cultivated in the presence of auxins developed roots, but the multiplication rate and hyperhydricity were not significantly affected (data not shown). These data differed from those reported by Misic et al. (2006) in S. brachyodon, for which the combination of $30.0 \mu \mathrm{M}$ BAP and $0.57 \mu \mathrm{M}$ IAA resulted in the highest shoot regeneration. However, these results indicated that the multiplication and rooting could be achieved in a single step using an appropriate combination of BAP and IAA.

Rooting of $2.22 \mu \mathrm{M}$ BAP grown plantlets was easily achieved after 15 days on MS hormone-free medium. In this condition, rooting percentage was $100 \%$. Similar results were reported in other Salvia species, including $S$. valentine, S. bancoana (Cuenca and Amo-Marco, 2000), and S. miltiorrhiza (Chen et al., 2005). However, in most Salvia species, a treatment with auxins stimulate rooting, increasing the number of roots and their length.

As can be observed in Table 2, the addition of 2.85 $\mu \mathrm{M}$ IAA to the culture medium significantly increased the number of roots, as well as root length in $S$. guaranitica. NAA and IBA did not significantly affect these parameters. However, even if not significant, a reduction in root length was observed with the highest concentrations of NAA, which were associated with basal callus formation. Root induction by auxins was previously reported in S. fruticosa (Arikat et al., 2004) and S. brachyodon (Misic et al., 2006).

Micropropagation rate and rooting efficiency were maintained in long term cultures (six months with subcultures every $30 \mathrm{~d}$ ). Rooted plantlets were acclimatized first in plastic chambers and then transferred to the greenhouse. The acclimatization occurred at a very high rate $(98 \%)$. All the plants transferred to the greenhouse (234 plants) were grown until maturity. No morphological changes were detected in micropropagated plants. Using the described protocol an average of 35 acclimatized plants were obtained per explant after three months.

In conclusion, the present results showed that in vitro propagation of $S$. guaranitica through axillary budding using MS medium supplemented with $2.22 \mu \mathrm{M}$ BAP for micropropagation and 2.85 $\mu \mathrm{M}$ IAA for rooting could be a reliable method, allowing the conservation, as well as the selection and propagation of good clones of this increasingly important ornamental plant. 
Table 2 - Effect of auxin concentration on rooting of micropropagated plantlets of $S$. guaranitica $($ Mean $\pm \mathrm{SE}, n=$ 60). Within each column, values followed by the same letter are not significantly different at the 5\% level according to Tukey's test.

\begin{tabular}{ccccc}
\hline IAA [ $\boldsymbol{\mu M}]$ & IBA [ $\boldsymbol{\mu M}]$ & NAA [ $\boldsymbol{\mu M}]$ & No. of roots per plantlet & Root length [cm] \\
\hline 0 & 0 & 0 & $2.52 \pm 0.60^{\mathrm{b}}$ & $1.08 \pm 0.27^{\mathrm{b}}$ \\
1.14 & 0 & 0 & $2.22 \pm 0.48^{\mathrm{b}}$ & $2.10 \pm 0.57^{\mathrm{ab}}$ \\
2.85 & 0 & 0 & $5.27 \pm 0.58^{\mathrm{a}}$ & $3.82 \pm 0.57^{\mathrm{a}}$ \\
5.71 & 0 & 0 & $2.60 \pm 0.47^{\mathrm{b}}$ & $1.72 \pm 0.44^{\mathrm{b}}$ \\
0 & 0.98 & 0 & $2.36 \pm 0.47^{\mathrm{b}}$ & $1.55 \pm 0.36^{\mathrm{b}}$ \\
0 & 2.46 & 0 & $2.83 \pm 0.58^{\mathrm{b}}$ & $2.72 \pm 0.56^{\mathrm{ab}}$ \\
0 & 4.92 & 0 & $2.00 \pm 0.49^{\mathrm{b}}$ & $1.37 \pm 0.38^{\mathrm{b}}$ \\
0 & 0 & 1.07 & $2.55 \pm 0.45^{\mathrm{b}}$ & $2.16 \pm 0.48^{\mathrm{ab}}$ \\
0 & 0 & 2.68 & $1.85 \pm 0.61^{\mathrm{b}}$ & $1.13 \pm 0.41^{\mathrm{b}}$ \\
0 & 0 & 5.36 & $2.11 \pm 0.56^{\mathrm{b}}$ & $0.75 \pm 0.29^{\mathrm{b}}$ \\
\hline
\end{tabular}

\section{RESUMO}

Segmentos nodais de plantas adultas de Salvia guaranitica cultivadas em estufa, foram utilizados para avaliar o efeito do meio de cultivo e reguladores de crescimento na micropropagação. A maior taxa de multiplicação foi obtida em meio Murashige and Skoog (MS) suplementado com $2.22 \mu \mathrm{M}$ de 6-benzilaminopurina (BAP). A melhor condição para enraizamento foi o meio MS acrescido de $2.85 \mu \mathrm{M}$ de ácido indol-3-acético (IAA). Plântulas enraizadas foram aclimatizadas com sucesso e exibiram desenvolvimento normal até a fase adulta. Utilizando o protocolo descrito, aproximadamente 35 plantas por explante foram obtidas após 3 meses.

\section{ACKNOWLEDGMENTS}

This work was supported by FAPERGS, CNPq and CAPES.

\section{REFERENCES}

Alberto, C.M.; Sanso, A.M. and Xifreda, C.C. (2003), Chromosomal studies in species of Salvia (Lamiaceae) from Argentina. Bot. J. Linnean Soc.. 141, 483-492.

Arikat, N.A.; Jawad, F.M.; Karam, N.S. and Shibli, R.A. (2004), Micropropagation and accumulation of essential oils in wild sage (Salvia fruticosa Mill.). Scientia Hort. 100, 193-202.
Avato, P.; Fortunato, I.M.; Ruta, C. and D`Elia, R. (2005), Glandular hairs and essential oils in micropropagated plants of Salvia officinalis L. Plant Sci. 169, 29-36.

Carrer, R.P.; Vanderlinde, R. and Echeverrigaray, S. (2007), Essential oil variation among Brazilian accessions of Salvia guaranitica Benth. Flavour Fragrance J. 22, 430-434.

Chen, U.C.; Shiau, Y.J.; Tsay, H.S. and Hsia, C.N. (2005), Influence of cytokinin and ventilating container closure on shoot proliferation and hyperhydricity of in vitro Salvia miltiorriza culture. $J$. Taiwan Agric. Res. 54, 93-102.

Chu, C.C.; Wang, C.C.; Sun, C.S.; Hsu, C.; Yin, K.C.; Chu, C.Y. and Bi, F.Y. (1975), Establishment of an efficient medium for anther culture of rice, through comparative experiments on the nitrogen sources. Scientia Sin. 18, 659-668.

Cuenca, S. and Amo-Marco, J.B. (2000), In vitro propagation of two Spanish endemic species of Salvia through bud proliferation. In Vitro cell. Dev. Biol. Plant 36, 225-229.

Echeverrigaray, S.; Basso, R. and Andrade, L.B. (2005), Micropropagation of Lavandula dentata from axillary buds of field-grown adult plants. Biol. Plant. 49, 439-442.

Frett, J.J. (1986) Tissue culture propagation of Salvia gregii. HortScience 21, 859.

Gamborg, O.L.; Miller, R.A. and Ojima, K. (1968) Nutrient requirements of suspension cultures of soybean root cells. Exp. Cell Res. 2, 209-212.

George, E.F. (1993), Plant propagation by tissue culture. Part. 1. The technology. Exegetics Ltd., Edington. 
Harley, R.M. and Heywood, C.A. (1992) Chromosome numbers in tropical American Labiatae. In: Advances in Labiatae Science, ed. R.M. Harley and T. Reynolds. The Royal Botanical Garden, Kew, London, 211-246.

Hosoki, T. and Tahara, Y. (1993), In vitro propagation of Salvia leucantha Cav. HortScience 28, 226.

Linsmaier, E.M. and Skoog, F. (1965), Organic growth factors requirements of tobacco tissue cultures. Physiol. Plant. 18, 100-127.

Mader, M.; Viola, H.; Wasowski, C.; Wolfman, C.; Waterman, P.G.; Medina, J.H. and Paladini, A.C. (1996), Cirsiliol and caffeic acid ethyl ester, isolated from Salvia guaranitica, are competitive ligands for the central benzodiazepine receptors. Phytomedicine 3, 29-31.

Medina, J.H.; Peña, C.; Levi de Stein, M.; Wolfman, C. and Paladini, A.C. (1989), Benzodiazepine-like molecules as well as other ligands for the brain benzodiazepine receptor are relative common constituents of plants. Biochem. Biophys. Res. Comm. 165, 547-553.
Misic, D.; Grubisic, D. and Konjeric, R. (2006), Micropropagation of Salvia brachyodon through nodal explants. Biol. Plant. 50, 473-476.

Murashige, T. and Skoog, F. (1962), A revised medium for rapid growth and bioassay with tobacco tissue culture. Physiol. Plant. 15, 473-497.

Pereira, C. (1971), Flora do Estado do Paraná. Família Labiatae. Leandra 1, 13-33.

Quoirin, M. and Lepoivre, P. (1997), Étude des milieux adaptes aux cultures in vitro de Prunus. Acta Hort. 78, 437-442.

Vallverdu, C.; Vila, R.; Lorenzo, D.; Paz, D.; Dellacasa, E.; Davies, P.; Vallamil, J.; Tomi, F.; Casanova, J. and Caniguera, S. (2005), Composition of the essential oil of cultivated Salvia guaranitica from Uruguay. Flavour Fragrance J. 20, 421-424.

Received: May 15, 2008; Revised: November 18, 2008; Accepted: October 21, 2009. 